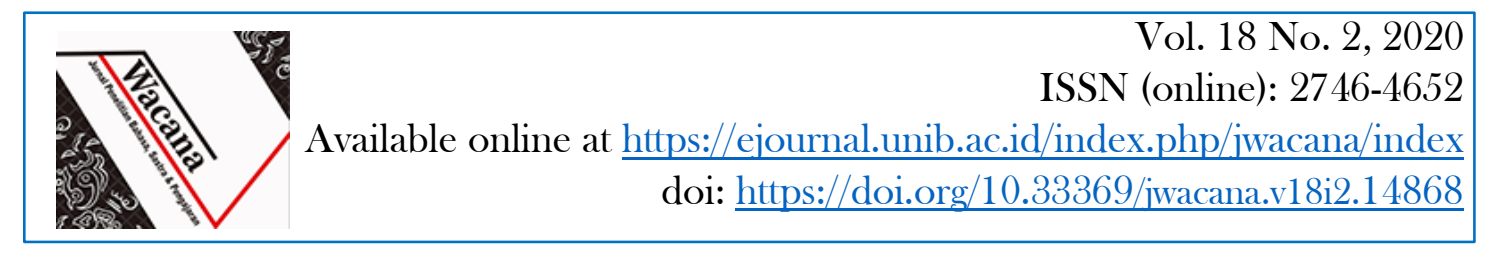

\title{
KAJIAN BAHASA DISFEMIA PADA KOLOM KOMENTAR NETIZEN DI INSTAGRAM
}

\author{
${ }^{1}$ Fatwa Rohhayati, ${ }^{2}$ Rokhmat Basuki, ${ }^{3}$ Irma Diani \\ Universitas Bengkulu \\ Korespondensi: fatwarohhavatibkl@gmail.com
}

\begin{abstract}
Abstrak
Tujuan penelitian ini untuk mendeskripsikan bentuk bahasa disfemia dan fungsi disfemia yang ada pada kolom komentar netizen di Instagram. Objek penelitian ini adalah disfemia yang terdapat dalam komentar netizen di Instagram@detik.com pada postingannya pada bulan Januari 2019. Datanya berupa kata, frasa, dan ungkapan yang menunjukkan adanya disfemia padaInstagram@detik.com. Sumber data berupa dokumen, yaitu komentar para netizen dalam Instagram @detik.com pada bulan Januari 2019. Teknik pengumpulan data pada penelitian ini adalah dokumentasi. Dokumentasi yang digunakan dalam penelitian ini adalah komentar netizen di Instagram @detikcom. Langkah-langkah yang digunakan untuk menganalisis data dalam penelitian ini adalah dengan cara analisis deskriptif. Penelitian ini berusaha menganalisis penggunaan disfemia yang terdapat dalam komentar para netizen di instagram. Hasil penelitian ini adalah sebagai berikut. Pertama bentuk kebahasaan disfemia pada kolom komentar netizen di Instagram @detik.com ada tiga, yang berupa kata, frasa, dan ungkapan. Kedua, fungsi disfemia pada komentar netizen di Instagram @detik.com adalah untuk menunjukkan kejengkelan, memberikan tekanan, menegaskan atau menguatkan makna, dan pengungkapan rasa marah atau kesal.
\end{abstract}

Kata kunci: disfemia, kolom komentar netizen, instagram.

\begin{abstract}
The purpose of this study was to describe the language form of and it's function of a dysfemia in the netizen's comments column on Instagram. The object of this study was dysfemia which were found in netizen's comments on Instagram @detik.com in the posts on January 2019. The data was in the form of words, phrases, and expressions that indicates the presence of dysfemia on Instagram @detik.com. The data source is in the form of documents, namely comments from netizens on Instagram @detik.com in January 2019. The data collection technique in this study was documentation. The documentation used in this study was the comments of netizens on Instagram@detikcom. The steps used to analyze the data in this study were descriptive analysis. This study attempted to analyze the use of dysfemia found in comments from netizens on Instagram. The results of this study are as follows: first, there were three forms of linguistic dysfemia, in the form of words, phrases and expressions. Second, the function of dysfemia in netizens' comments on Instagram @detik.com is to show aggravation, put pressure, affirm or reinforce meaning, and express anger or resentment.
\end{abstract}

Keywords: dysfemia, netizens comments column, instagram. 


\section{PENDAHULUAN}

Manusia dan bahasa merupakan suatu komponen yang tidak dapat dipisahkan. Dengan bahasa manusia dapat dengan mudah berkomunikasi antara satu dengan yang lainnya. Bahasa adalah sistematik, yaitu memiliki aturan atau pola. Aturan tersebut dapat dilihat melalui dua hal, yaitu sistem bunyi dan sistem makna (Suhardi, 2013:21). Bahasa adalah sebuah sistem artinya bahasa itu dibentuk oleh sejumlah komponen yang berpola secara tetap dan dapat dikaidahkan (Chaer dan Agustin, 2004:11). Dengan bahasa manusia dapat dengan mudah berkomunikasi antara satu dengan yang lainnya.

Fungsi bahasa sebagai alat komunikasi merupakan suatu komponen utama. Dalam berkomunikasi tentu dibutuhkan bahasa yang baik agar maksud yang akan disampaikan oleh penutur dapat diterima dengan baik oleh mitra tutur sesuai dengan konteksnya. Untuk itu keberadaan bahasa sebagai alat komunikasi sangatlah penting bagi manusia.

Bahasa dapat dibedakan berdasarkan dua jenis, yaitu ragam bahasa lisan dan bahasa tulis. Bahasa yang ada pada kolom komentar Instagram merupakan salah satu contoh dari ragam bahasa lisan yang dituliskan. Instagram adalah sebuah aplikasi media sosial yang berfungsi untuk membagikan foto atau video kepada para penggunanya.

Saat ini Instagram merupakan salah satu media sosial yang paling banyak digunakan dan diminati oleh masyarakat di Indonesia. Penggunanya mulai dari remaja, orang dewasa, hingga orangtua. Hal ini dikarenakan pada Instagram kita juga dapat memperoleh informasi secara cepat dan akurat dari postingan pengguna yang lain. Informasipun terlihat lebih menarik karena disertai adanya foto ataupun video.

Media sosial yang berfungsi untuk membagikan foto atau video ini banyak dimanfaatkan oleh sebagian orang untuk mempromosikan bisnis mereka. Banyak sekali akun-akun bisnis yang bertebaran di instagram. Mulai dari bisnis kuliner, pakaian, kosmetik, alat elektronik. perabotan rumahtangga, dll. Selain itu ada juga yang mempromosikan tempat-tempat wisata. Hal ini tentunya membuat instagram sebagai media sosial yang semakin banyak diminati oleh banyak orang.

Media sosial Instagram ini juga disertai dengan berbagai fitur. Salah satunya yaitu fitur komentar yang dapat digunakan oleh pengguna lain untuk mengomentari foto atau video yang diposting. Namun dibalik itu semua, dalam media sosial Instagram dengan kebebasan orang berkomentar banyak sekali ditemukan berbagai komentar-komentar yang menjurus pada kata kasar (disfemia) yang penulis temukan.

Menurut Chaer (2002:145) disfemia adalah usaha untuk mengganti kata yang bermakna halus atau bermakna biasa dengan kata yang maknanya kasar. Makna kasar merupakan maksud atau arti suatu kata yang memiliki nilai rasa kasar tidak menyenangkan dan dapat menyinggung atau menimbulkan reaksi tidak mengenakkan. Dalam media sosial Instagram, netizen cenderung terpancing untuk memberikan komentar-komentar menggunakan bahasa kasar (disfemia) untuk menyampaikan perasaan atas berita yang disajikan. Para netizen tersebut menggunakan kata berdisfemia yang akan menambah gereget dan menguatkan komentar mereka.

Bentuk kebahasaan disfemia dibagi menjadi tiga jenis, kata, frasa, dan ungkapan. Menurut Chaer (2007:162) kata adalah satuan bahasa yang memiliki satu pengertian. Contoh bentuk pemakaian disfemia yang berupa kata yaitu, 1) dengan seenaknya Israel mencaplok wilayah Mesir itu. Kata mencaplok merupakan disfemia untuk menggantikan frasa mengambil dengan begitu saja, 2) polisi menjebloskannya ke dalam penjara. Kata menjebloskannnya merupakan kata disfemia untuk menggantikan kata memasukkan.

Frasa merupakan satuan gramatikal yang dibentuk dari dua buah kata atau lebih dan mengisi salah satu fungsi sintaksis yang berupa subjek, predikat, objek, dan keterangan (Chaer, 2002:39). Contoh bentuk pemakai disfemia yang berupa frasa yaitu. 1) Khasmir banjir darah 14 tewas. Frasa banjir darah dipilih sebagai disfemia dari kata kisruh, 2) bila Mega naik menjadi 
presiden, maka sasaran tembak yang empuk adalah Taufik Kemal. Frasa sasaran tembak dipakai sebagai disfemia untuk menggantikan kata target.

Idiom atau ungkapan adalah konstruksi unsur bahasa yang saling memilih, masingmasing unsurnya mempunyai makna yang ada karena bersama yang lain (Sudrayat, 2006:39). Contoh bentuk pemakaian disfemia yang berupa ungkapan masuk kotak dalam kalimat, 1) Liem Swie King sudah masuk kotak. Ungkapan masuk kotak merupakan disfemia untuk menggantikan kata kalah.

Fungsi pemakaian disfemia dapat digunakan seseorang dalam berbagai situasi. Hal ini bergantung dengan situasi yang sedang dialami orang tersebut. Berikut beberapa fungsi pemakaian disfemia:

a. Menunjukkan Kejengkelan

Menurut Chaer (2002:145) usaha atau gejala pengasaran biasanya dilakukan orang dalam situasi yang tidak ramah atau menunjukkan kejengkelan. Seperti pada kata menjebloskan yang dipakai untuk menggantikan kata memasukkan seperti dalam kalimat Polisi menjebloskannya ke dalam sel. Kata memasukkan memiliki makna membiarkan masuk dengan begitu saja, sedangkan kata menjebloskan memiliki makna memasukkan dengan sekuat-kuatnya ke dalam lubang dan sebagainya. Untuk itu maka kata menjebloskan lebih kuat digunakan untuk menunjukkan kejengkelan atas situasi yang ada.

b. Memberikan Tekanan

Kata yang sebenarnya bernilai kasar tetapi sengaja digunakan untuk lebih memberi tekanan tetapi tanpa terasa kekasarannya (Chaer, 2002:145). Misalnya kata menggondol yang biasa dipakai untuk binatang, seperti pada kalimat anjing menggondol tulang. Namun demikian, kata menggondol juga dipakai untuk mengganti kata membawa dalam kalimat Akhirnya regu bulu tangkis kita berhasil menggondol pulang piala Thomas Cup itu. Kata membawa memiliki makna memegang atau mengangkat sesuatu sambil berjalan atau bergerak dari satu tempat ke tempat lain, sedangkan kata menggondol memiliki makna membawa dengan menggunakan mulut. Kata mengondol tersebut sengaja digunakan untuk memberikan tekanan pada kalimat tersebut.

c. Menegaskan atau Menguatkan Makna

Usaha untuk mengasarkan atau disfemisme sengaja dilakukan untuk mencapai efek pembicaraan menjadi tegas (Chaer, 1995:315). Misalnya kata merusak diganti dengan kata membobol dalam kalimat sekelompok maling berhasil membobol mesin ATM. Kata merusak memiliki makna menjadikan rusak atau merusak dengan sengaja, sedangkan kata membobol memiliki makna merusak dengan paksa. Sehingga kata membobol lebih kuat digunakan dalam kalimat tersebut untuk menegaskan dan menguatkan makna yang ada dalam situasi pada kalimat tersebut.

d. Pengungkapan Rasa Marah atau Kesal

Kata-kata berbentuk disfemisme ini digunakan ketika keadaan emosi seseorang sedang dalam keadaan naik atau sedang melonjak (Susanti, 2014:11). Hal ini tentu juga diikuti oleh nada suara yang tinggi dan ekspresi wajah yang bisa berubah memerah. Misalnya pada ungkapan dasar kau bangsat! Ungkapan bangsat tersebut memiliki makna orang yang memiliki tabiat jahat atau buruk. Kata bangsat digunakan dalam situasi pada kalimat tersebut untuk menunjukkan rasa marah.

Penelitian ini bertujuan untuk menemukan bentuk kebahasaan disfemia dan fungsi disfemia pada kolom komentar netizen di instgram. Penelitian ini nantinya diharapkan dapat bermanfaat bagi peneliti bahasa di masa mendatang yang meneliti permasalahan yang sama, yakni mengetahui bentuk kebahasaan dan fungsi disfemia. Bagi guru Bahasa Indonesia penelitian ini dapat digunakan dalam mengajarkan kepada siswa mengenai berbahasa yang baik, tidak kasar, dan berperilaku santun. 


\section{METODE}

Penelitian ini menggunakan metode deskriptif dengan pendekatan kualitatif. Metode deskriptif dalam penelitian ini digunakan untuk mendeskripsikan bentuk bahasa, makna, dan fungsi disfemia pada kolom komentar netizen di Instagram. Data dalam penelitian ini adalah kata, frasa, dan ungkapan yang menunjukkan adanya disfemia padaInstagram @detik.com. Penelitian ini menggunakan sumber data berupa dokumen, yaitu komentar para netizen dalam Instagram @detik.com pada bulan Januari 2019. Pengumpulan data dilakukan dengan cara dokumentasi. Dokumentasi yang digunakan dalam penelitian ini adalah screnshoot komentar netizen di Instagram@detikcom.

Langkah-langkah yang digunakan untuk menganalisis data yaitu a) membaca komentarkomentar netizen, kemudian melakukan pendataan komentar yang termasuk ke dalam disfemia, b) mengidentifikasi kata berdisfemia berdasarkan kriteria bentuk disfemia, seperti kata, frasa, dan ungkapan, c) mengklasifikasikan kata berdisfemia berdasarkan kriteria bentuk disfemia, seperti kata, frasa, dan ungkapan, d) melakukan analisis dan pendeskripsian terhadap bentuk dan makna disfemia berupa kata, frasa, dan ungkapan, e) menjelaskan fungsi kata, frasa, dan ungkapan disfemia.

\section{HASIL DAN PEMBAHASAN}

Penelitian ini dilakukan pada penggunaan bahasa disfemia atau bahasa kasar. Disfemia adalah usaha untuk mengganti kata yang bermakna halus atau bermakna biasa dengan kata yang maknanya kasar. Makna kasar merupakan maksud atau arti suatu kata yang memiliki nilai rasa kasar tidak menyenangkan dan dapat menyinggung atau menimbulkan reaksi tidak mengenakkan. Bentuk kebahasaan disfemia yang digunakan dalam kolom komentar para netizen di Instagram pada akun @detik.com adalah berupa kata yang pertama yaitu kata kapok, kebobrokan, koar-koar, kerangkeng, onar, jebloskan, pengecut, bacot, gebuki, cambuk, nyinyir, mencibir, jeruji, kebusukan, kecanduan, bangkrut, penjara, musnah, digerebek, rakus, kalap, berkedok, bongkar, merosot, melontarkan, ngerampok, komplotan, setimpal, tumbal, gadungan, jeblosin, dirampas, hancur, tembus, gebrakan, goblok, bobrok, becus. Kedua berupa frasa yaitu frasa manusia bejat, si pengecut, orang stress, gongong kafir, istri durjana, manusia rakus, maling bejat, jeruji besi, mencekik rakyat, perampokan halus, gelandangan politik, kerangkeng besi, tukang nyinyir, tukang nyontek, manusa laknat, pemalak gelap. Dan yang ketiga ungkapan yaitu ungkapan sampah masyarakat, manusia sampah, panas hati, kambing hitam, sampah masyarakat, aji mumpung, adu domba, kelinci percobaan, kebakaran jenggot, busuk hati, mulutmu harimaumu. Sedangkan fungsi disfemia dalam kolom komentar para netizen di Instagram pada akun @detik.com adalah untuk menunjukkan kejengkelan, memberikan tekanan, menegaskan atau menguatkan makna, dan pengungkapan rasa marah atau kesal.

Bentuk dan fungsi disfemia pada kolom komentar netizen di Instagram pada akun @detik.com akan dijabarkan sebagai berikut.

1. Bentuk Disfemia Berupa Kata dan Fungsinya

Data [1]

[1] [III/ D3/01-(01-2019/1]

@minusnol : Kebobrokan sebuah lapas, penampakan kaya gini sudah jadi rahasia umum. Belum lagi kalau mau jenguk harus selipin uang pelicin buat org dalem. Perih lah ya

Berita : "Permasalahan over kapasitas seakan tiada akhir. Satu rutan/ LP bisa diisi 8 kali lipat dari kapasitas seharusnya. Alhasil, mereka tidur berdesak-desakan. Bahkan ada yang tidur bak kelelawar."

Kebobrokan pada komentar netizen tersebut merupakan salah satu bentuk bahasa disfemia yang termasuk dalam bentuk kata. Kata kebobrokan merupakan disfemia dari kata kerusakan. Kata kebobrokan memiliki nilai rasa yang lebih kasar dibandingkan dengan kata 
kerusakan. Kata kebobrokan memiliki makna rusak sama sekali. Rusak di sini mengacu pada rusaknya sebuah sistem maupun kondisi. Sedangkan kata kerusakan memiliki makna sudah tidak sempurna atau tidak utuh lagi. Keduanya sama-sama memiliki makna rusak dan sudah tidak dapat digunakan lagi. Makna kebobrokan pada komentar netizen tersebut adalah sebuah kerusakan sistem pada lapas yang memang banyak terjadi di beberapa lapas dan sudah menjadi sebuah rahasia umum.

Fungsi penggunaan disfemia pada komentar tersebut adalah untuk menegaskan atau menguatkan makna. Hal ini sesuai dengan berita, yaitu permasalahan over kapasitas penghuni lapas yang diisi hingga 8 kali lipat dari kapastias seharusnya. Sehingga netizen menggunakan kata kebobrokan untuk lebih menegaskan atau menguatkan makna dari kata rusak menjadi bobrok berdasarkan berita yang ada.

Data [2]

[2] [III/ D7/02-01-2019/83]

@arsatatakalo : Berani pulang...langsung ditangkap dan jebloskan ke bui

Berita : "Imam Besar FPI Habib Rizieq Shihab memimpin deklarasi 2019 Ganti Presiden dari Jabal Rahmah,di padang Arafah, provinsi Mekah bersama warga Indonesia yang bermukim di sana."

Jebloskan pada komentar netizen tersebut merupakan salah satu bentuk bahasa disfemia yang termasuk dalam bentuk kata. Kata jebloskan merupakan disfemia dari kata memasukkan. Kata jebloskan memiliki nilai rasa yang lebih kasar dibandingkan dengan kata memasukkan. Kata jebloskan memiliki makna memasukkan dengan sekuat-kuatnya, memasukkan sesuatu dengan cara kasar. Sedangkan kata memasukkan memiliki makna memberikan masuk atau menempatkan. Keduanya sama-sama memiliki makna membiarkan sesuatu masuk. Makna jebloskan pada komentar netizen tersebut adalah memasukkan ke bui Habieb Rizieq jika ia nanti kembali lagi ke Indonesia.

Fungsi penggunaan disfemia pada komentar tersebut adalah untuk menegaskan atau menguatkan makna. Hal ini sesuai dengan berita, yaitu Imam besar FPI Habib Rizieq Shihab yang memimpin deklarasi 2019 ganti presiden di Jabal Rahmah Mekah sehingga netizen menggunakan kata menjebloskan untuk lebih menegaskan atau menguatkan makna dari kata memasukkan menjadi menjebloskan berdasarkan berita yang ada.

\section{Bentuk Disfemia Berupa Frasa dan Fungsinya}

Data [7]

[7] [III/D10/02-01-2019/84]

@ rocliana : Si pengecut

Berita : "Imam Besar FPI Habib Rizieq Shihab memimpin deklarasi 2019 Ganti Presiden dari Jabal Rahmah,di padang Arafah, provinsi Mekah bersama warga Indonesia yang bermukim di sana."

Si pengecut merupakan salah satu bentuk bahasa disfemia yang termasuk ke dalam bentuk frasa. Frasa si pengecut merupakan disfemia dari frasa si penakut. Frasa si pengecut memiliki nilai rasa yang lebih kasar dibandingkan dengan frasa si penakut. Frasa si pengecut memiliki makna orang yang munafik atau orang yang hanya berani berkoar namun tidak berani memberikan bukti kebenaran. Sedangkan frasa si penakut memiliki makna orang yang takut atau mudah takut. Keduanya sama-sama memiliki makna orang yang memiliki sifat penakut. Makna si pengecut pada komentar netizen tersebut adalah sikap Habieb Rizieq yang dinilai penakut dengan melakukan pendeklarasian 2019 ganti presiden di luar negeri, yaitu di Jabal Rahmah Mekah. Hal ini sesuai dengan konteks, yaitu Imam besar FPI Habib Rizieq Shihab yang memimpin deklarasi 2019 ganti presiden di Jabal Rahmah Mekah.

Fungsi penggunaan disfemia pada komentar tersebut adalah untuk pengungkapan rasa marah atau kesal. Hal ini sesuai dengan berita, yaitu Imam besar FPI Habib Rizieq Shihab yang 
memimpin deklarasi 2019 ganti presiden diJabal Rahmah Mekah. Untuk itu dapat disimpulkan bahwa frasa si pengecut lebih kuat digunakan untuk mengungkapan rasa marah atau kesal berdasarkan berita yang ada.

Data [9]

[9] [III/ D80/25-01-2019/26]

@umishahadh : Lho kok dhani masih kluyuran??? kirain udah masuk kerangkeng besi

Berita : "Fadli Zon 'meniru' aksi pemotongan rambut Presiden Joko Widodo (Jokowi). Aksi pemotongan rambut Waketum Partai Gerindra itu pun dilakukan di lokasi yang sama dengan Jokowi, yakni di Danau Situbagendit, Garut, Jawa Barat. Tak sendiri, Caleg Gerindra Ahmad Dhani, serta musisi Sang Alang ikut serta dalam aksi potong rambut tersebut. Padahal awalnya Fadli zon mengatakan bahwa apa yang dilaukan Jokowi adalah pencitraan, kemudian berujung ia meniru adegan potong rambut tersebut."

Kerangkeng besi pada komentar netizen tersebut merupakan salah satu bentuk bahasa disfemia yang termasuk dalam bentuk frasa. Frasa Kerangkeng besi merupakan disfemia dari bui. Frasa kerangkeng besi memiliki nilai rasa yang lebih kasar dibandingan dengan kata bui. Frasa kerangkeng besi memiliki makna kurungan berpagar besi yang lazimnya digunakan untuk mengurung binatang. Sedangkan kata bui memiliki makna penjara yang lazim dihuni bagi orang yang menjalani hukuman. Keduanya sama-sama memiliki makna tempat mendekam bagi orang yang sedang menjalani hukuman. Makna kerangkeng besi pada komentar netizen tersebut adalah hukuman bui bagi Ahmad Dhani yang seharusnya sudah berlangsung. Ahmad Dhani terjerat kasus tindak pidana ujaran kebencian yang membuatnya terancam harus mendekam di bui. Dengan keberadaanya yang ada pada saat cukur rambut bersama Fadli Zon membuat netizen mempertayakannya.

Fungsi penggunaan disfemia pada komentar netizen tersebut adalah untuk menegaskan atau menguatkan makna. Hal ini terlihat dari berita yang ada. Oleh karena itu, netizen menggunakan kata kerangkeng besi untuk lebih menguatkan makna berdasarkan berita yang ada.

3. Bentuk Disfemia Berupa Ungkapan dan Fungsinya

Data [11]

[11] [III/D1/01-01-2019/1]

@halim_buger : Matikan aja kalo bisa manusia-manusia sampah masyarakat kayak gini, bikin semak aja pun dunia.

Berita :"Permasalahan over kapasitas seakan tiada akhir. Satu rutan/ LP bisa diisi 8 kali lipat dari kapasitas seharusnya. Alhasil, mereka tidur berdesak-desakan. Bahkan ada yang tidur bak kelelawar."

Sampah masyarakat pada komentar netizen tersebut merupakan salah satu bentuk bahasa disfemia yang berupa ungkapan. Ungkapan sampah masyarakat pada komentar netizen tersebut merupakan disfemia dari penghuni lapas. Sampah masyarakat merupakan ungkapan yang memiliki nilai rasa kasar dibandingan dengan penghuni lapas. Ungkapan sampah masyarakat memiliki makna orang yang tidak berguna dan tidak diharapkan kehadirannya di tengah-tengah masyarakat. Sedangkan frasa penghuni lapas memiliki makna tahanan yang mendekam di dalam penjara karena sedang menjalani hukuman. Keduanya sama-sama memiliki makna orang yang memiliki kelakuan tidak baik. Makna sampah masyarakat pada komentar netizen tersebut adalah orang-orang yang berada dalam lapas yang merupakan pesakitan yang memang pantas diberikan hukuman.

Fungsi penggunaan disfemia pada komentar tersebut adalah sebagai pengungkapan rasa marah atau kesal. Hal ini sesuai dengan berita, yaitu mengenai permasalahan over kapasitas penghuni lapas. Sehingga netizen menggunakan ungkapan sampah masyarakat untuk mengungkapkan rasa marah atau kesal untuk berkomentar berdasarkan berita yang ada. 
Data [12]

[12] [III/D86/27-01-2019/105]

@andrizal29019 : Busuk hati ini yg mau jdi presiden

Berita : "Saat memberikan sambutan di acara Deklarasi Nasional Alumni Perguruan Tinggi seluruh Indonesia untuk Prabowo-Sandiaga, Prabowo Subianto tiba-tiba menggulung lengan seperti yang sering dilakukan pesaingnya."

Busuk hati pada komentar netizen tersebut merupakan salah satu bentuk bahasa disfemia yang berupa ungkapan. Ungkapan busuk hati merupakan disfemia dari ungkapan iri hati. Busuk hati ini merupakan ungkapan yang memiliki nilai rasa yang lebih kasar dibandingkan dengan ungkapan iri hati. Ungkapan busuk hati memiliki makna sifat iri hati dan dengki dengan apa yang oranglain punya. Sedangkan iri hati memiliki makna kurang senang melihat kelebihan orang lain. Keduanya sama-sama memiliki makna orang yang memiliki sifat tidak baik dan tidak patut untuk ditiru. Makna busuk hati pada komentar netizen tersebut adalah sifat Prabowo yang iri hati dan dengki pada pesaingnnya, hingga apa yang dilakukan pesaingannya (Jokowi) ia coba tirukan untuk menyindir. Hal ini terlihat dari konteks, yaitu Saat memberikan sambutan di acara Deklarasi Nasional Alumni Perguruan Tinggi seluruh Indonesia untuk Prabowo-Sandiaga, Prabowo Subianto tiba-tiba menggulung lengan seperti yang sering dilakukan pesaingnya.

Fungsi penggunaan disfemia pada komentar netizen tersebut adalah untuk menunjukkan kejengkelan. Hal ini berdasarkan berita yang ada, sehingga netizen menggunakan kata busuk hati untuk lebih menunjukkan kejengkelannya berdasarkan berita yang ada.

\section{KESIMPULAN}

Berdasarkan hasil penelitian dan pembahasan yang telah dilakukan, maka dapat disimpulkan bentuk bahasa disfemia dan fungsi disfemia yang terdapat pada kolom komentar netizen di Instagram @detik.com adalah sebagai berikut:

1. Bentuk bahasa disfemia pada kolom komentar netizen di Instagram @detik.com ada tiga, yang pertama berupa kata yaitu kata kapok, kebobrokan, koar-koar, kerangkeng, onar, jebloskan, pengecut, bacot, gebuki, cambuk, nyinyir, mencibir, jeruji, kebusukan, kecanduan, bangkrut, penjara, musnah, digerebek, rakus, kalap, berkedok, bongkar, merosot, melontarkan, ngerampok, komplotan, setimpal, tumbal, gadungan, jeblosin, dirampas, hancur, tembus, gebrakan, goblok, bobrok, becus. Kedua berupa frasa yaitu frasa manusia bejat, si pengecut, orang stress, gongong kafir, istri durjana, manusia rakus, maling bejat, jeruji besi, mencekik rakyat, perampokan halus, gelandangan politik, kerangkeng besi, tukang nyinyir, tukang nyontek, manusa laknat, pemalak gelap. Dan yang ketiga ungkapan yaitu ungkapan sampah masyarakat, manusia sampah, panas hati, kambing hitam, sampah masyarakat, aji mumpung, adu domba, kelinci percobaan, kebakaran jenggot, busuk hati, mulutmu harimaumu.

2. Fungsi bahasa disfemia pada kolom komentar netizen di Instagram @detik.com ada empat, yaitu menunjukkan kejengkelan, memberikan tekanan, menegaskan atau menguatkan makna, dan pengungkapan rasa marah atau kesal.

\section{SARAN}

Penelitian tentang kajian bahasa disfemia pada kolom komentar netizen di instagram ini menemukan adanya bentuk kebahasaan disfemia yang berupa kata, frasa, ungkapan dan fungsi disfemia yaitu untuk menunjukkan kejengkelan, memberikan tekanan, menegaskan atau menguatkan makna, pengungkapan rasa marah atau kesal. Penelitian ini masih terbatas pada disfemia yang ditinjau dari sudut pandang semantik dan masih banyak permasalahan lain yang belum dikaji dalam penelitian ini. Untuk itu bagi peneliti selanjutnya diharapkan dapat mengembangkan kajiannya mengenai disfemia yang ditinjau dari sudut pandang pragmatik. 
Penelitian ini nantinya juga dapat digunakan bagi peneliti lain yang ingin meneliti mendalam mengenai disfemia. Bagi pembaca hasil penelitian ini dapat digunakan untuk mengetahui penggunaan bahasa disfemia dalam kehidupan sehari-hari, terutama dalam penggunaanya ketika berkomentar di media sosial.

\section{DAFTAR PUSTAKA}

Chaer, Abdul. (1995). Pengantar Semantik Bahasa Indonesia. Jakarta: Rineka Cipta.

Chaer, Abdul. (2002). Pengantar Semantik Bahasa Indonesia. Jakarta: PT Asdi Mahasatya.

Chaer, Abdul. (2004). Sosiolinguistik Sebuah Perkenalan Awal. Jakarta: Rineka Cipta.

Chaer, Abdul. (2007). Linguistik Umum. Jakarta: Rineka Cipta.

Sudrayat, Yayat. (2016). Makna Dalam Wacana Prinsip-prinsip Semantik dan Pragmatik . upi.edu, 36.

Suhardi. (2013). Pengantar Linguistik Umum. Yogyakarta: Ar-Ruzz Media.

Susanti, Junita Ardi. (2014). Analisis Penggunaan Disfemisme Dalam Masyarakat Sasak Dialek A-A Di Desa Aikmel Barat Dan Relevansinya Dengan Materi Pembelajaran Bahasa Indonesia Di Smp. Mataram: Universitas Mataram. 